\title{
Prerequisite to the Translation of the Toba Batak Modalisation into English through Semantic Features
}

\author{
Drs. Bloner Sinurat, M.Hum. \\ (Universitas HKBP Nommensen, Medan-Pematangsiantar, North Sumatera - Indonesia)
}

\begin{abstract}
This article deals with a semantic feature analysis executed in the process of translation of Toba Batak Modalisation into English. The data in this article are all derived from actual daily conversation conducted by the native speaker. The analysis in this research is focused to see the semantic feeatures of modalisation both in Toba Batak language and English, which is based on the modalisation theories used by Saeed (2009), Saragih (2004), and Halliday (1994). Through the analysis, it can be concluded that both Toba Batak language and English have the same sorts of modalisation, but with different realization. Based on its types, modalisation in Toba Batak language are all realized by modal adjuncts, but in English, they can be realized by finite modal operators, modal adjuncts, or both. Based on its value, modalisation has a high, medium and low value in both laguages; and based on its orientation, modalisation can be classified either as subjective or objective, explicit or implicit in both languages. After conducting the analysis on their semantic features it can be concluded that the Toba Batak modalisation can be equivalently translated into English.
\end{abstract}

Keywords: semantic features, prerequisite, modalisation, Toba Batak

\section{Introduction}

This article, from the perspective of translation study, concerns with a restricted problem. It is so called since the issue discussed in this article is focused on the translation of a certain linguistic device called modalisation from Toba Batak into English. Modalisation, as a part of modality, is an important semantic category which operates at the sentence level, which allow the speakers to express his or her personal judgement consisting of various degrees of probability and usuality in a proposition (Saeed, 2009:138).

Language, in addition to being part of the culture, also reflects the attitude of the language users. Therefore it is easily understood that the study of the meaning of language, for example the meaning of modalisation used in Toba Batak language and English, is also closely related to the culture, customs or traditions of the language users of both languages. Vocabulary used to express or define a particular society is culturally specific and referred to as cultural words (Whorf, 1941:293).

Toba Batak language has various types of modalisation of its own, which belong to various types, semantic values, and orientation. In relation with the translation activity which is conducted nowadays, especially the translation of various texts from Toba Batak language into English on one hand and the development of translation theory on the other hand, a research needs to be conducted so as to see how all types of modalisation are possibly translated into English. In other words, this research is focused to find out if the Toba Batak modalisation have the same semantic features with the English modalisation, and see if they can possibly be translated equivalently into English.

In line with the globalization era and the current advances in communication technology, mutual understanding among countries is totally required in order to be able to have the same perception of how to improve the human civilization all over the world. It seems that cooperation between countries all over the world can possibly be intensified and improved through a mutual understanding between a certain language users and the others. Batak Toba has a lot of indigenous cultural texts and events; and they need to be introduced to the other ethnic groups in Indonesia and other foreign countries by means of translation.

The transfer of cultural knowledge can be acquired either through a direct experience or by other means such as television, internet, or other related literatures. In other words, through the acquisition of the linguistic and cultural knowledge, one may interact with the other people easily and appropriately. As a matter of facts, nowadays, a text can be easily rendered into other languages by means of machine-aided translation process. It is obviously seen that in this globalization era, translation plays an important role in transferring various sorts of information from one country to the others. Translation is especially used in transferring science and technology from the developed countries to the developing and underdeveloped countries, and it is mainly acknowledged and used in cross-cultural communication. 


\subsection{Translation Studies}

\section{Literature Review}

The issues concerning Translation Studies factually cover an immence amount of concepts pertaining to the theories of how the translation is done (Vinay and Darbelnet in Munday, 2012: 86-89), the quality of the translation products (Hatim and Munday, 2004:184), translators' qualifications (Robinson, 2008:11-13), translator's responsibilities (Robinson, 2008:25-26), as well as the effects or consequences of translation on the human life (Cronin in Hatim and Munday, 2012:112). Based on the theoretical perspectives, it can be seen that translation also concerns with various issues such as idiology, approach, methode, strategy or technique, and its relation to other sciences or subjects. Based on the quality of the translation products, it is also related to the concept of accuracy, i.e., the levels of equivalence or shift, and the degrees of truth which are to be preserved or created as well. Other important issues related to translation also pertain to the consequences of mistranslation, and how communication and social relationship may be effected either individually, constitutionally, or crossculturally.

A great number of researches have been conducted in order to find translation universals, and more researchers are getting more interested to get involved in various translation studies in order to establish a comprehensive translation theory. The researches on translation studies done so far have resulted in both language-pair restricted theories and cultural-pair restricted theories which in reality pertains only to the western cultural area (Hatim and Munday, 2004:130). Anyhow, scientists and linguists keep on trying to find an easy way to do the translation, such as a computer-aided translation (CAT), but various sorts of softwares used nowadays (e.g., Google Translation, Catmt, Tecnotrad, Dejavu-L, Tw-Users, U-Cat, Tradosuser, Tefdl, Sdlx, Transit_Termstar, Wordfast) are not yet satisfactorily established and available in handling the real problem of translation. Although these softwares are all available and really helpful, but as a matter of fact a few minor changes are to be made, and the translation is to be updated manually due to the linguistic and cultural diversities between the source language and the target language (Robinson, 2008:31-32).

\subsection{Translation Process}

Translation process, according to Bell (1991: 229-231), actually refers to any significant activities executed by the translator in the translation of a source text into the target text. These activities either include the physiological and psychological activities executed by the translator in the translation of the source text into the target text. The physiological activities, as what Bell says, involve reading the Source Language Text (SLT) and writing the Target Language text (TLT); and the psychological activities refer to the cognitive process and the decision-making executed by the translator consisting of three stages such as 1) Reception, filtering, storage and initial processing of information by the sensory information system, 2) Final analysis, short-term storage and second filtering of the data by the short-term memory system, and 3) Accessing the long-term memory and integrating new information within the long-term memory database. Based on this theory, this research refers to a part of cognitive process and the decision-making executed by the translator in finding out the meaning or the semantic features of the Toba Batak modalisations, and how they are to be translated into English.

The translation process which is considered as the combination of the physiological and psychological activities is considered as a three-stage process involving 1) Reading and understanding, 2) Deverbalization, and 3) Re-expression (Lederer in Munday, 2012: 97-98). This can be based on either top-down translation approach or bottom-up translation approach.

In line with this research, this study is focused to see the translator's psychological activities, i.e., the cognitive process and decision-making process and procedures executed by the translator in rendering the meaning of modalisation from the Toba Batak language into English.

Since the nuances of meaning also concern with the writers' commitment or belief, it proves that the translation of modalisation from Toba Batak language into English becomes an important issue to discuss. In line with the cross-cultural communication in today's globalized world, translation is something that is growing phenomenally and has developed enormously in the past twenty years (Hatim and Munday, 2004:xvii). Thus it's obviously seen that the translation of the Toba Batak modalisation into English is an interesting topic to discuss since it is to be viewed from the linguistic and cultural perspectives in both languages.

In doing a translation, according to Larson (1984:3), the nuances of meaning can certainly be rendered when the translator can comprehend the lexicon, grammatical structure, and the socio-cultural context of the text both in the source text (ST) and the target text (TT). In other words, the translator is to be capable of understanding the intention of the writer in the source language (SL) on one hand, and how it is ought to be properly transfered into the target language (TL) on the other hand.

\subsection{Semantic Features of Modalisation}

Semantics is the branch of linguistics that addresses the problem of meaning in a language. Semantics, as a branch of linguistics, deals with the study of both the lexical meaning and the compositional meaning in a 
language. The one dealing with the study of the lexical meaning is called lexical semantics, and the other one dealing with the study of the compositional meaning is called compositional semantics. It's further explained that semantics is not part of a pragmatics and vice versa, but both have an independent field of study as a branch of linguistics. In other words semantics concerns with the study of literal meaning of words or sentences, but pragmatics concerns with the study of the meaning of utterances (Siregar, 2010). According to Kreidler (1998) semantics is assigned to draw the speaker's knowledge in communicating facts, feelings, goals and products of imagination to others. According to Cruse (2000) it examines the meaning of the word and various aspects related to the production and interpretation of the sentence, the relation of language and formal logic system which is seen as a proposition.

In doing a translation, analysis on the semantic features is to be made as a prerequisite for the translation of a source text into a target text. Semantic features of modalisation discussed in this research include the type, value, and its orientation. Based on its type, modalisation is a linguistic device used to express probability and usuality; based on its value, it pertains to the level of commitment of the speaker, i.e., high, mid, or low. Based on its orientation, modalisation can be subjective or objective, explicit or implicit (Saragih, 2010; Saeed, 2009; Halliday, 1994; Thompson, 1996). The value of a modalisation is considered high when a personal judgement of probability and usuality lies near the positive polar; it is considered low when a personal judgement of probability and usuality lies near the negative polar; it is considered medium when a personal judgement of probability and usuality lies about half way between the positive and negative polar. In other words, a modalisation with a high value is used to express the most probable or frequent condition of personal judgement; and the one with a low value is used to express the least probable or the least frequent condition of personal judgement; and the one with a medium value is used to express the condition half way between the most and the least probable or the least frequent condition of personal judgement. In terms of its orientation, a subjective modality is one used to express the personal judgement by the first person, but when it expressed by the third person or by using impersonal it, it is regarded as objective modalisation. A modalisation is regarded as an explicit one when it is clearly represented by the speaker by using modals, but it is regarded as an implicit modality when it is expressed or coded by modal adjuncts containing mental process such as I think, I reckon, I believe, I doubt, I am doubtful, I am worried, there is a worry, there is a confidence, which can be replaced by probably. The type of modalisation expressed this way is used as if to show that the personal judgement belongs to the speaker (Saragih, 2004:22). Halliday (1994:357-360) called this type of modalisation as grammatical metaphor, and Eggins (2004:174-175) called it as mood adjunct.

Modalisation, viewed from the perspective of functional grammar, pertains to the linguistic device used to express probability and usuality (Halliday, 1994). But from the perspective of semantics, it is categorized as epistemic modality which is used to indicate the level of knowledge or belief of the speaker towards the factuality of a preposition. (Saeed, 1997; Siregar, 2010).

It has been mentioned previously that modalisation, from the semantic prespective, pertains to the level of knowledge or belief of the speaker towards the factuality of a preposition, which may either exist or lie near the positive or the negative polar, which is used especially to express "probability" and "usuality" (Saragih, 2004:22; Halliday, 1994:89). Modalisation in English is specifically expressed or realized by finite modal operators, modal adjuncts, and both finite modal operators and modal adjuncts (Halliday, 1994:89). But in Toba Batak language they are all realized by modal adjuncts (Bloner, 2011: 42-43). Based on their semantic features, the English modalisation (Saragih, 2004: 22; Halliday, 1994: 76) can be drawn as in Table 1.

Table 1. Semantic Features of the English Modalisation

\begin{tabular}{|l|l|l|}
\hline Value & Probability & Usuality \\
\hline High & $\begin{array}{l}\text { must be, } \\
\text { certainly }\end{array}$ & Always \\
\hline Medium & $\begin{array}{l}\text { will be, would be } \\
\text { probably }\end{array}$ & usually, ever \\
\hline Low & $\begin{array}{l}\text { may be, can be, could be, } \\
\text { might be } \\
\text { possibly, perhaps }\end{array}$ & $\begin{array}{l}\text { sometimes, } \\
\text { never, seldom }\end{array}$ \\
\hline
\end{tabular}

According to (Bloner, 2011:42; Sinaga, 2008:153), there are some modalisation that are commonly used in Batak Toba language. Since the researcher is a native speaker of Batak Toba language, the semantic features of modalisation in Toba Batak language can be drawn as in Table 2.

Table 2. Semantic Features of Toba Batak Modalisation

\begin{tabular}{|l|l|l|}
\hline Value & Probability & Usuality \\
\hline High & pasti (do) & holan, maos, totop \\
\hline Medium & olo do & sipata \\
\hline Low & mungkin (do), ra & sasahali, hea, so hea \\
\hline
\end{tabular}




\section{Research Methods}

This study is a descriptive qualitative research. The data used in this study are primary collected through the dialog in which the researcher is also get involved called as a participant observation (Mahsum in Dalimunte 2013), and interviews with a number of Toba Batak native speakers. The data are then transcribed, reduced and restricted to the clauses containing various types and values of modalisation used by the Toba Batak native speakers. Then the data are displayed, analyzed, and classified in order to draw the conclusion (Miles and Huberman, 1994:10-11). The data analysis in this research is based on the theory of modalisation used by Saragih (2004) and Halliday (1994). In addition to the above theories, the analysis is also verified by means of the researcher's knowledge about Toba Batak language (Sudaryanto in Dalimunte 2013). There are 20 clauses used as data in this research, and each modalization which is realized in the clause is analysed according to its type, value, and orientation translated from Toba Batak language into English. In other words, the analysis in this research is based on a contrastive study on the semantic features of modalisation in terms of the type, value, and orientation of modalisation used in both languages.

\subsection{Data Collection}

\section{Data Collection And Data Analysis}

The data used in this research are all derived from the expressions used by the Toba Batak native speakers. The data are all transcribed and limited on the clauses containing modalisation. The data collected so far can be displayed as in the following clauses:

1. Pasti tibu do ro hami. 'We'll certainly come soon.'

2. Boi sajo do hatop nasida ro. 'They may actually come soon.'

3. Olo do hatop nasida ro. 'Perhaps they'll come soon.'

4. Marmotor do ra nasida. 'They will probably come by bus.'

5. Mungkin di jabu do nasida. 'May be they're at home.'

6. Huhilala hatop do nasida ro. I think they will come soon.'

7. Di rohangku nungnga sae be i. According to my opinion it's enough.'

8. Hupingkir dumenggan do i. ' I think it's better.'

9. Manurut ahu nungnga sae be i. 'According to my consideration, it's already enough.'

10. Holan na tarlambat do ho. 'You always come late.'

11. Maos do pinaingot ibana. 'I always remind him.'

12. Ganup ari do ibana tu si. 'He goes there every day.'

13. Ganup tingki do i mangido hepeng. 'He always asks for money.'

14. Jotjot do niulahon si songon i. 'I usually do something like that.'

15. Somal do taulahon songon i. 'We commonly do something like that.'

16. Sipata boi do i. 'It sometimes will do.'

17. Sasahali ndang pola sala i. 'It sometimes doesn't matter.'

18. Hea do hami pajumpang. 'We surely ever met.'

19. Ndang hea i ro tu jabungku. ' He never comes to my house.'

20. So hea nasida marbadai. 'They never have a quarrel.'

\subsection{Data Analysis}

It has been mentioned previously that the analysis in this research is based on a contrastive study on the semantic features of modalisation used in both Toba Batak language and English. The semantic features analysed pertain to their types, values and orientation Saragih (2004) and Halliday (1994). Based on this theory, the data analysis is done as follows:

Data 1

\begin{tabular}{|l|l|l|}
\hline Modalisation & Toba Batak & English \\
\cline { 2 - 3 } & pasti & Certainly \\
\hline Type & Probability & Probability \\
\hline Value & High & High \\
\hline Orientation & Subjective/Explicit & Subjective/Explicit \\
\hline Clause & Pasti tibu do ro hami. & $\begin{array}{l}\text { We'll certainly come } \\
\text { soon. }\end{array}$ \\
\hline
\end{tabular}


Data 2

\begin{tabular}{|l|l|l|}
\hline \multirow{2}{*}{ Modalisation } & Toba Batak & English \\
\cline { 2 - 3 } & boi sajo & May \\
\hline Type & Probability & Probability \\
\hline Value & Low & Low \\
\hline Orientation & Objectiive/Explicit & Objective/Explicit \\
\hline Clause & $\begin{array}{l}\text { Boi sajo do hatop } \\
\text { nasida ro. }\end{array}$ & $\begin{array}{l}\text { They may actually } \\
\text { come soon. }\end{array}$ \\
\hline
\end{tabular}

Data 3

\begin{tabular}{|l|l|l|}
\hline \multirow{2}{*}{ Modalisation } & Toba Batak & English \\
\cline { 2 - 3 } & olo do & Perhaps \\
\hline Type & Probability & Probability \\
\hline Value & Low & Low \\
\hline Orientation & Subjective/Explicit & Subjective/Explicit \\
\hline Clause & Olo do hatop nasida ro. & $\begin{array}{l}\text { Perhaps they'll come } \\
\text { soon. }\end{array}$ \\
\hline
\end{tabular}

Data 4

\begin{tabular}{|l|l|l|}
\hline \multirow{2}{*}{ Modalisation } & Toba Batak & English \\
\cline { 2 - 3 } & ra & Probably \\
\hline Type & Probability & Probability \\
\hline Value & Low & Low \\
\hline Orientation & Explicit & Explicit \\
\hline Clause & $\begin{array}{l}\text { Marmotor do ra } \\
\text { nasida. }\end{array}$ & $\begin{array}{l}\text { They will probably } \\
\text { come by bus. }\end{array}$ \\
\hline
\end{tabular}

Data 5

\begin{tabular}{|l|l|l|}
\hline \multirow{2}{*}{ Modalisation } & Toba Batak & English \\
\cline { 2 - 3 } & mungkin & may be \\
\hline Type & Probability & Probability \\
\hline Value & Low & Low \\
\hline Orientation & Explicit & Explicit \\
\hline Clause & $\begin{array}{l}\text { Mungkin di jabu do } \\
\text { nasida. }\end{array}$ & $\begin{array}{l}\text { May be they're at } \\
\text { home. }\end{array}$ \\
\hline
\end{tabular}

Data 6

\begin{tabular}{|l|l|l|}
\hline \multirow{2}{*}{ Modalisation } & Toba Batak & English \\
\cline { 2 - 3 } & Huhilala & I think \\
\hline Type & Probability & Probability \\
\hline Value & Medium & Medium \\
\hline Orientation & Implicit & Implicit \\
\hline Clause & $\begin{array}{l}\text { Huhilala hatop do } \\
\text { nasida ro. }\end{array}$ & $\begin{array}{l}\text { I think they will come } \\
\text { soon. }\end{array}$ \\
\hline
\end{tabular}

Data 7

\begin{tabular}{|l|l|l|}
\hline Modalisation & Toba Batak & English \\
\cline { 2 - 3 } & di rohangku & $\begin{array}{l}\text { according to my } \\
\text { opinion }\end{array}$ \\
\hline Type & Probability & Probability \\
\hline Value & Medium & Medium \\
\hline Orientation & Implicit & Implicit \\
\hline Clause & $\begin{array}{l}\text { Di rohangku } \\
\text { nungnga sae be i. }\end{array}$ & I think it's enough. \\
\hline
\end{tabular}

Data 8

\begin{tabular}{|l|l|l|}
\hline \multirow{2}{*}{ Modalisation } & Toba Batak & English \\
\cline { 2 - 3 } & hupingkir & I think \\
\hline Type & Probability & Probability \\
\hline Value & Medium & Medium \\
\hline Orientation & Implicit & Implicit \\
\hline Clause & $\begin{array}{l}\text { Hupingkir } \\
\text { dumenggan do i. }\end{array}$ & I think it's better. \\
\hline
\end{tabular}


Data 9

\begin{tabular}{|l|l|l|}
\hline \multirow{2}{*}{ Modalisation } & Toba Batak & English \\
\cline { 2 - 3 } & manurut ahu & according to me \\
\hline Type & Probability & Probability \\
\hline Value & Medium & Medium \\
\hline Orientation & Implicit & Implicit \\
\hline Clause & $\begin{array}{l}\text { Manurut ahu } \\
\text { nungnga sae be i. }\end{array}$ & $\begin{array}{l}\text { According to my } \\
\text { consideration, it's } \\
\text { already enough. }\end{array}$ \\
\hline
\end{tabular}

Data 10

\begin{tabular}{|l|l|l|}
\hline \multirow{2}{*}{ Modalisation } & Toba Batak & English \\
\cline { 2 - 3 } & holan & Always \\
\hline Type & Probability & Probability \\
\hline Value & High & High \\
\hline Orientation & Explicit & Explicit \\
\hline Clause & $\begin{array}{l}\text { Holan na tarlambat } \\
\text { do ho. }\end{array}$ & $\begin{array}{l}\text { You always come } \\
\text { late. }\end{array}$ \\
\hline
\end{tabular}

Data 11

\begin{tabular}{|l|l|l|}
\hline \multirow{2}{*}{ Modalisation } & Toba Batak & English \\
\cline { 2 - 3 } & maos & Always \\
\hline Type & Usuality & Usuality \\
\hline Value & High & High \\
\hline Orientation & Explicit & Explicit \\
\hline Clause & $\begin{array}{l}\text { Maos do pinaingot } \\
\text { ibana. }\end{array}$ & I always remind him. \\
\hline
\end{tabular}

Data 12

\begin{tabular}{|l|l|l|}
\hline \multirow{2}{*}{ Modalisation } & Toba Batak & English \\
\cline { 2 - 3 } & ganup ari & every day \\
\hline Type & Usuality & Usuality \\
\hline Value & High & High \\
\hline Orientation & Explicit & Explicit \\
\hline Clause & $\begin{array}{l}\text { Ganup ari do } \\
\text { ibana tu si. }\end{array}$ & $\begin{array}{l}\text { He goes there every } \\
\text { day. }\end{array}$ \\
\hline
\end{tabular}

Data 13

\begin{tabular}{|l|l|l|}
\hline \multirow{2}{*}{ Modalisation } & Toba Batak & English \\
\cline { 2 - 3 } & ganup tingki & Always \\
\hline Type & Usuality & Usuality \\
\hline Value & High & High \\
\hline Orientation & Explicit & Explicit \\
\hline Clause & $\begin{array}{l}\text { Ganup tingki do i } \\
\text { mangido hepeng. }\end{array}$ & $\begin{array}{l}\text { He always asks for } \\
\text { money. }\end{array}$ \\
\hline
\end{tabular}

Data 14

\begin{tabular}{|l|l|l|}
\hline Modalisation & Toba Batak & English \\
\cline { 2 - 3 } & jotjot & Usually \\
\hline Type & Usuality & Usuality \\
\hline Value & Medium & Medium \\
\hline Orientation & Explicit & Explicit \\
\hline Clause & $\begin{array}{l}\text { Jotjot do niulahon } \\
\text { si songon i. }\end{array}$ & $\begin{array}{l}\text { I usually do something } \\
\text { like that. }\end{array}$ \\
\hline
\end{tabular}

Data 15

\begin{tabular}{|l|l|l|}
\hline \multirow{2}{*}{ Modalisation } & Toba Batak & English \\
\cline { 2 - 3 } Type & somal & Commonly \\
\hline Value & Usuality & Usuality \\
\hline Orientation & Medium & Medium \\
\hline Clause & Explicit & Explicit \\
\hline & $\begin{array}{l}\text { Somal do taulahon } \\
\text { songon i. }\end{array}$ & $\begin{array}{l}\text { We commonly do } \\
\text { something like that. }\end{array}$ \\
\hline
\end{tabular}


Data 16

\begin{tabular}{|l|l|l|}
\hline \multirow{3}{*}{ Modalisation } & Toba Batak & English \\
\cline { 2 - 3 } & sipata & Sometimes \\
\hline Type & Usuality & Usuality \\
\hline Value & Low & Low \\
\hline Orientation & Implicit & Implicit \\
\hline Clause & Sipata boi do i. & It sometimes will do. \\
\hline
\end{tabular}

Data 17

\begin{tabular}{|l|l|l|}
\hline \multirow{2}{*}{ Modalisation } & Toba Batak & English \\
\cline { 2 - 3 } Type & sasahali & Sometimes \\
\hline Value & Usuality & Usuality \\
\hline Orientation & Low & Low \\
\hline Clause & Implicit & Implicit \\
\hline & $\begin{array}{l}\text { Sasahali ndang pola } \\
\text { sala i. }\end{array}$ & $\begin{array}{l}\text { It sometimes doesn't } \\
\text { matter. }\end{array}$ \\
\hline
\end{tabular}

Data 18

\begin{tabular}{|l|l|l|}
\hline \multirow{2}{*}{ Modalisation } & Toba Batak & English \\
\cline { 2 - 3 } & hea & Ever \\
\hline Type & Usuality & Usuality \\
\hline Value & Medium & Medium \\
\hline Orientation & Exlicit hami & $\begin{array}{l}\text { We surely ever } \\
\text { met. }\end{array}$ \\
\hline Clause & $\begin{array}{l}\text { Hea do } \\
\text { pajumpang. }\end{array}$ \\
\hline
\end{tabular}

Data 19

\begin{tabular}{|l|l|l|}
\hline \multirow{3}{*}{ Modalisation } & Toba Batak & English \\
\cline { 2 - 3 } & ndang hea & Never \\
\hline Type & Usuality & Usuality \\
\hline Value & Low & Low \\
\hline Orientation & Explicit & Explicit \\
\hline Clause & $\begin{array}{l}\text { Ndang hea i ro tu } \\
\text { jabungku. }\end{array}$ & $\begin{array}{l}\text { He never comes to } \\
\text { my house. }\end{array}$ \\
\hline
\end{tabular}

Data 20

\begin{tabular}{|l|l|l|}
\hline \multirow{2}{*}{ Modalisation } & Toba Batak & English \\
\cline { 2 - 3 } & so hea & Never \\
\hline Type & Usuality & Usuality \\
\hline Value & Low & Low \\
\hline Orientation & Explicit & Explicit \\
\hline Clause & $\begin{array}{l}\text { So hea nasida } \\
\text { marbadai. }\end{array}$ & $\begin{array}{l}\text { They never have a } \\
\text { quarrel. }\end{array}$ \\
\hline
\end{tabular}

\subsection{Findings}

After analysing all the data, there are some findings which significantly show the existence modalisation both in Toba Batak language and English. The findings are drawn as the following:

1. Based on the data analysis it is found out that all modalisation are realized by modal adjuncts in Toba Batak language, but they can be realized by i) Finite Modal Operators, ii) Modal Adjuncts, and iii) the combination of Finite Modal Operators and Modal Adjuncts in English (Saragih, 2004; Halliday, 1994).

2. Both Toba Batak language and English have the same sorts of modalisation that can be used to express probability and usuality.

3. Based on the data collected so far, there are less number of modalisation in Toba Batak language than those in English.

4. The Toba Batak language and English have the same semantic features of modalisation.

5. The Toba Batak modalisations have significantly different grammatical features than those in English.

\subsection{Conclusion}

\section{Conclusion And Suggestion}

Based on the data analysis, i.e., a contrastive analysis on the semantic features of modalisation used both in Toba Batak language and English, a conclusion can be drawn as follows:

1. Based on its type, Toba Batak language and English have the same type of modalisation that can be used to express "probability" and "usuality". 
2. Based on its value, Toba Batak language and English have the same value of modalisation that can be used to express "probability" and "usuality".

3. Based on the orientation, both Toba Batak language and English have either subjective or objective, and explicit or implicit orientation.

4. Since modalisation used in Batak Toba language have the same semantic features (type, value, and orientation), it can be concluded that the Toba Batak modalisations can be equivalently translated into English.

\subsection{Suggestion}

The data used in this research are quite restricted, which are all derived from a limited number of subjects and context of situation. More researches are therefore required so as to find a comprehensive types and use of modalisation in Toba Batak language, and how they ought to be translated into English.

\section{References}

[1]. Bell, Roger T. 1991: Translation and Translating: Theory and Practice.London: Longman Group UK Limited.\}

[2]. Bloner. 2011. Peranan Kearifan Lokal Dalam Pembentukan Karakter Bangsa. Medan: Departemen Sastra Daerah, Fakultas Ilmu Budaya, Universitas Sumatera Utara.

[3]. Cruse, D. Alan. Meaning in Language: An Introduction to Semantics and Pragmatics. Oxford: Oxford University Press.

[4]. Dalimunte, Muhammad. 2013. Modality in Angkolanese: A Semantic Perspective. Medan: Postgraduate program of University of North Sumatera.

[5]. Eggins, Suzanne. 2004. An Introduction to Systemic Functional Linguistics. New York: Continuum International Publishing Group.

[6]. Kreidler, Charles W. 1998. Introducing English Semantics. New York: Routledge.

[7]. Miles, Matthew B. And Huberman Michael A. 1994. Qualitative Data Analysis. Sec.ed.London: Sage Publication.

[8]. Munday, Jeremy. 2012: Introducing Translation Studies-theories and application. London and Newyork: Routledge Taylor \& Francis Group.

[9]. Sinaga, Anicetus B. 2008, Tata Bahasa Batak Toba. Medan: Penerbit Bina Media Perintis.

[10]. Siregar, Bahren Umar. 2010. 1. Semantik dan Bahasa (Makalah). Medan: Sekolah Pascasarjana USU.

[11]. Saeed, John I. 1997. Semantics. China: Blackwell Publishers Ltd.

[12]. O'Grady, Williamand Dobrovolsky, Michael. 1996. Contemporary Linguistic Analysis. Toronto: Copp Clark Ltd.

[13]. Saragih, Amrin. 2004. Introducing Functional Grammar. Medan: English Department, Faculty of Languages and Arts, The State University of Medan.

[14]. Thompson, Geoff. 1996. Introducing Functional Grammar. China: Edward Arnold (Publishers) Ltd. 